\title{
CATARACT EXTRACTION IN AN ENGLISH POPULATION
}

BY

\author{
F. I. CAIRD, MARY HUTCHINSON, AND ANTOINETTE PIRIE \\ From the Radcliffe Infirmary, Oxford, and the Nuffield Laboratory of Ophthalmology, \\ University of Oxford
}

The epidemiology of cataract has attracted little attention. The definition of cataract is difficult enough to make surveys of its prevalence in populations of doubtful value. One partial solution is to consider only cataract of a degree sufficient to be operated upon. Fuchs (1960) has published figures showing a very wide variation in the proportions of patients with cataract admitted to various ophthalmological centres throughout the world, but the information is of little use unless the reasons for admission of patients without cataract are known. Halevi and Landau (1962) studied operations for senile cataract in Israel in 1956-57; they make comparisons with figures from Sweden and Thailand, the value of which is greatly diminished by lack of detail. Sorsby (1962) has published estimates of rates of extraction of cataract of all types in England and Wales for 1958.

The purpose of the following study is to provide detailed estimates of cataract extraction rates for a clearly-defined English population.

\section{METHODS}

A study was made of the case records of all patients, seen privately and through the National Health Service, over the age of 20 years who had a cataract extracted in the Oxford Eye Hospital in the years 1957 to 1962 (Caird, Hutchinson, and Pirie, 1964).

Patients were divided, by their address at the time of operation, into those living inside and those living outside an area from which come virtually all patients undergoing ophthalmic operations in the Oxford Eye Hospital, since there is no other hospital or nursing home within or immediately outside the area where such operations are conducted. The area is somewhat smaller than the Oxford Record Linkage Study area (Acheson, 1964,) and comprises Oxford County Borough, the Urban Districts of Bicester, Thame, and Witney, the Municipal
Boroughs of Abingdon, Chipping Norton, and Woodstock, and the Rural Districts of Abingdon, Bullingdon, Chipping Norton, Ploughley, and Witney. The civilian population of the area aged 20 years or more at the time of the 1961 Census was 195,193 (General Register Office, 1964).

Cataract was considered secondary when it was thought to have a congenital basis, or when it occurred either in association with other possibly causal ocular disease, in particular trauma, iridocyclitis, and glaucoma, or with general disease other than diabetes (e.g. dystrophia myotonica, hypoparathyroidism). It was considered diabetic if the patient was known or found to be a diabetic at the time of operation. Diabetes was diagnosed on customary biochemical criteria (a random blood sugar of $180 \mathrm{mg}$. per $100 \mathrm{ml}$. or more, a fasting blood sugar level of $130 \mathrm{mg}$. per $100 \mathrm{ml}$., or more, or a glucose tolerance curve of diabetic type (Working Party, 1962)). All other cataracts were considered senile.

The indications for operation on the first and second eye differ, and those for the first are thought to be more uniform (but see Fig. 3 and Discussion): operations on the two eyes have therefore been considered separately, the operations on the first eye, which make up 69 per cent. of the total operations for senile cataract within the defined area, area, being analysed in detail (Caird and others, 1964).

\section{RESULTS}

Table I (opposite) gives, by age and sex, the population of the area and the numbers of patients operated on and of operations carried out in the 6-year period under study. The proportion of private patients is approximately 10 per cent., and tends to increase with age in both sexes.

Fig. 1 (opposite) shows the derived rates of cataract extraction per 10,000 at risk per annum. 
CATARACT EXTRACTION IN AN ENGLISH POPULATION

TABLE I

CATARACT EXTRACTIONS, BY AGE AND SEX, AND TYPE OF CATARACT, 1957-62

\begin{tabular}{|c|c|c|c|c|c|c|c|c|c|c|c|}
\hline \multirow{3}{*}{$\begin{array}{c}\text { Age } \\
\text { (yrs) }\end{array}$} & \multirow{3}{*}{ Sex } & \multirow{3}{*}{$\begin{array}{c}\text { Total } \\
\text { Population }\end{array}$} & \multicolumn{9}{|c|}{ Type of Cataract } \\
\hline & & & \multicolumn{3}{|c|}{ Senile } & \multicolumn{2}{|c|}{ Diabetic } & \multicolumn{2}{|c|}{ Secondary } & \multicolumn{2}{|c|}{ Total } \\
\hline & & & $\begin{array}{c}\text { First } \\
\text { Opera- } \\
\text { tions }\end{array}$ & $\begin{array}{c}\text { All } \\
\text { Patients }\end{array}$ & $\begin{array}{c}\text { All } \\
\text { Opera- } \\
\text { tions }\end{array}$ & $\begin{array}{c}\text { All } \\
\text { Patients }\end{array}$ & $\begin{array}{c}\text { All } \\
\text { Opera- } \\
\text { tions }\end{array}$ & $\begin{array}{c}\text { All } \\
\text { Patients }\end{array}$ & $\begin{array}{c}\text { All } \\
\text { Opera- } \\
\text { tions }\end{array}$ & Patients & $\begin{array}{c}\text { Opera- } \\
\text { tions }\end{array}$ \\
\hline $20-29$ & $\begin{array}{l}\mathbf{M} \\
\mathbf{F}\end{array}$ & $\begin{array}{l}24,296 \\
19,609 \\
\end{array}$ & $\begin{array}{l}0 \\
0\end{array}$ & $\begin{array}{l}0 \\
0\end{array}$ & $\begin{array}{l}0 \\
0\end{array}$ & $\begin{array}{l}0 \\
0\end{array}$ & $\begin{array}{l}0 \\
0\end{array}$ & 2 & 2 & 2 & 2 \\
\hline $30-39$ & $\begin{array}{l}\mathbf{M} \\
\mathbf{F}\end{array}$ & $\begin{array}{l}19,497 \\
18,701\end{array}$ & $\begin{array}{l}1 \\
0\end{array}$ & $\begin{array}{l}1 \\
0\end{array}$ & 2 & $\begin{array}{l}0 \\
0\end{array}$ & $\begin{array}{l}0 \\
0\end{array}$ & $\begin{array}{l}3 \\
2\end{array}$ & 3 & $\begin{array}{l}4 \\
2\end{array}$ & $\begin{array}{l}5 \\
3\end{array}$ \\
\hline $40-49$ & $\begin{array}{l}\mathbf{M} \\
\mathbf{F}\end{array}$ & $\begin{array}{l}17,695 \\
18,085 \\
\end{array}$ & $\begin{array}{l}3 \\
1\end{array}$ & $\begin{array}{l}3 \\
1 \\
\end{array}$ & $\begin{array}{l}3 \\
1 \\
\end{array}$ & $\begin{array}{l}0 \\
3 \\
\end{array}$ & $\begin{array}{l}0 \\
6 \\
\end{array}$ & $\begin{array}{l}7 \\
3 \\
\end{array}$ & $\begin{array}{l}7 \\
3 \\
\end{array}$ & $\begin{array}{r}10 \\
7\end{array}$ & $\begin{array}{l}10 \\
10 \\
\end{array}$ \\
\hline $50-59$ & $\begin{array}{l}\mathbf{M} \\
\mathbf{F}\end{array}$ & $\begin{array}{l}17,476 \\
17,374 \\
\end{array}$ & $\begin{array}{l}24 \\
22\end{array}$ & $\begin{array}{l}24 \\
26\end{array}$ & $\begin{array}{l}33 \\
32 \\
\end{array}$ & $\begin{array}{l}2 \\
5 \\
\end{array}$ & 8 & 8 & $\begin{array}{l}3 \\
9\end{array}$ & $\begin{array}{l}29 \\
39\end{array}$ & \begin{tabular}{|l|}
38 \\
49
\end{tabular} \\
\hline $60-69$ & $\mathbf{M}$ & $\begin{array}{l}10,139 \\
12,900 \\
\end{array}$ & $\begin{array}{l}39 \\
62 \\
\end{array}$ & $\begin{array}{l}43 \\
68 \\
\end{array}$ & $\begin{array}{l}55 \\
87 \\
\end{array}$ & $\begin{array}{l}6 \\
10 \\
\end{array}$ & \begin{tabular}{|l|}
8 \\
13 \\
\end{tabular} & $\begin{array}{l}6 \\
9\end{array}$ & $\begin{array}{r}7 \\
12 \\
\end{array}$ & $\begin{array}{l}55 \\
87 \\
\end{array}$ & $\begin{array}{r}70 \\
112 \\
\end{array}$ \\
\hline $70-79$ & $\begin{array}{l}\mathbf{M} \\
\mathbf{F}\end{array}$ & $\begin{array}{l}5,413 \\
8,633 \\
\end{array}$ & $\begin{array}{r}58 \\
106 \\
\end{array}$ & $\begin{array}{r}51 \\
118 \\
\end{array}$ & $\begin{array}{r}72 \\
142 \\
\end{array}$ & $\begin{array}{r}5 \\
24\end{array}$ & $\begin{array}{r}66 \\
26 \\
\end{array}$ & 17 & $\begin{array}{l}10 \\
18 \\
\end{array}$ & $\begin{array}{r}75 \\
159\end{array}$ & $\begin{array}{c}88 \\
186 \\
\end{array}$ \\
\hline $80-89$ & $\mathbf{M}$ & $\begin{array}{l}1,661 \\
3,259 \\
\end{array}$ & $\begin{array}{l}19 \\
54 \\
\end{array}$ & $\begin{array}{l}222 \\
59 \\
\end{array}$ & $\begin{array}{l}26 \\
61 \\
\end{array}$ & $\begin{array}{l}5 \\
6 \\
\end{array}$ & $\begin{array}{l}5 \\
6 \\
\end{array}$ & $\begin{array}{l}5 \\
8 \\
\end{array}$ & $\begin{array}{l}5 \\
8 \\
\end{array}$ & $\begin{array}{l}32 \\
73 \\
\end{array}$ & $\begin{array}{l}36 \\
75 \\
\end{array}$ \\
\hline $90+$ & $\begin{array}{l}\mathbf{M} \\
\mathbf{F}\end{array}$ & $\begin{array}{l}120 \\
335 \\
\end{array}$ & $\begin{array}{l}2 \\
4 \\
\end{array}$ & $\begin{array}{l}2 \\
4 \\
\end{array}$ & $\begin{array}{l}2 \\
4 \\
\end{array}$ & $\begin{array}{l}0 \\
0 \\
\end{array}$ & $\begin{array}{l}0 \\
0\end{array}$ & $\begin{array}{l}0 \\
0\end{array}$ & $\begin{array}{l}0 \\
0\end{array}$ & $\begin{array}{l}2 \\
4 \\
\end{array}$ & 2 \\
\hline \multirow[t]{2}{*}{ All Ages } & $\mathbf{M}$ & $\begin{array}{l}96,297 \\
98,896 \\
\end{array}$ & $\begin{array}{l}146 \\
249\end{array}$ & $\begin{array}{l}156 \\
276\end{array}$ & $\begin{array}{l}193 \\
327\end{array}$ & $\begin{array}{l}18 \\
48\end{array}$ & $\begin{array}{l}21 \\
59\end{array}$ & $\begin{array}{l}35 \\
47 \\
\end{array}$ & $\begin{array}{l}37 \\
53\end{array}$ & $\begin{array}{l}209 \\
371\end{array}$ & $\begin{array}{l}251 \\
439\end{array}$ \\
\hline & Total & 195,193 & 395 & 432 & 520 & 66 & 80 & 82 & 90 & 580 & 690 \\
\hline
\end{tabular}
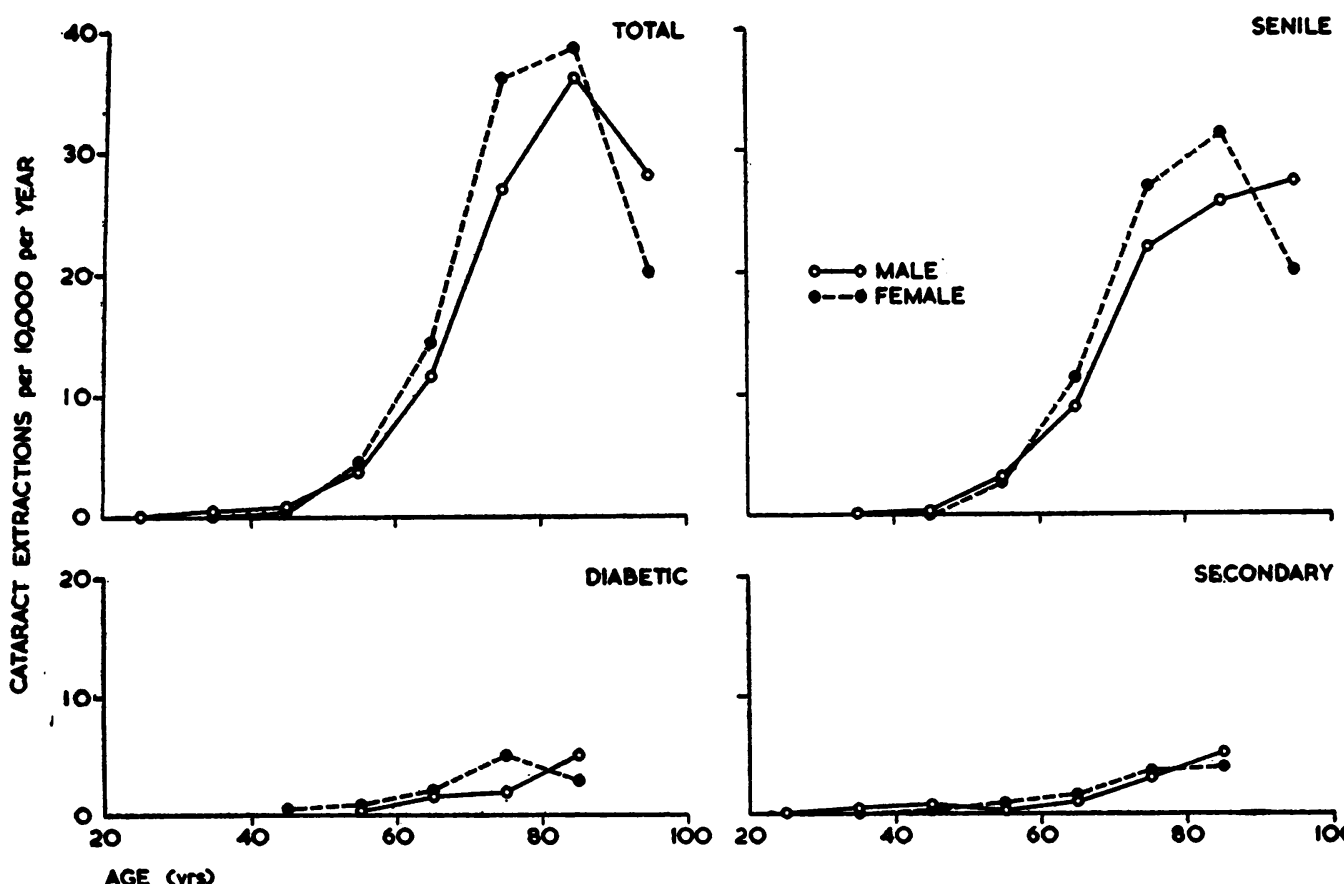

Fro. 1.-Cataract extractions per 10,000 at risk per year: all cataracts, senile, diabetic, and secondary cataracts. 
Fig. 2 shows the rates for first operation for senile cataract.

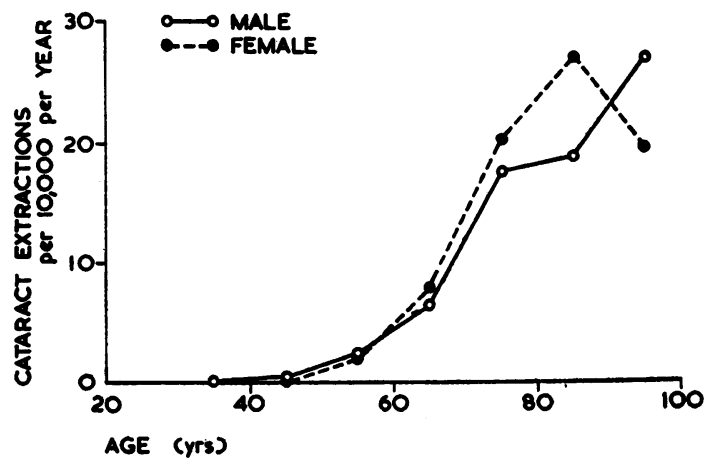

Fig. 2.-First extraction of senile cataract, per 10,000 at risk per year.

The rates for extraction of senile cataract rise rapidly with age, increasing approximately three-fold for each decade between the sixth and eighth. Over the age of 80 years, the increase is less. First operations account at all ages for about three-quarters of all operations for senile cataract. The rates for men and women are nearly equal in the sixth decade, but at ages between 60 and 90 the rates for women are higher than those for men. Over the age of 90 these rates mean little because of the small numbers.

The rates for diabetic and secondary cataract are about 15 and 17 per cent. respectively of those for senile cataract, and account together for about a quarter of all operations. Both rates increase steadily with age (Fig. 1). In the secondary group the cataract in most of the younger patients was due to trauma or to iridocyclitis, and in the older to glaucoma or iridocyclitis.

Tables II and III compare the findings in this study with those of Sorsby (1962) for England and Wales and of Halevi and Landau (1962) for Israel respectively.

TABLE II

RATES IN OXFORD AND ENGLAND AND WALES (Sorsby, 1962) OF ALL CATARACT EXTRACTIONS PER 10,000 PER YR

\begin{tabular}{|c|c|c|c|c|c|c|c|}
\hline \multirow{3}{*}{$\begin{array}{l}\text { Sex } \\
\text { Area }\end{array}$} & \multirow{3}{*}{$\begin{array}{l}\cdots \\
\ldots\end{array}$} & \multicolumn{3}{|c|}{ Male } & \multicolumn{3}{|c|}{ Female } \\
\hline & & \multirow{2}{*}{$\begin{array}{c}\text { Eng- } \\
\text { land } \\
\text { and } \\
\text { Wales } \\
\text { Admis- } \\
\text { sions }\end{array}$} & \multicolumn{2}{|c|}{ Oxford } & \multirow{2}{*}{$\begin{array}{c}\text { Eng- } \\
\text { land } \\
\text { and } \\
\text { Wales } \\
\text { Admis- } \\
\text { sions }\end{array}$} & \multicolumn{2}{|c|}{ Oxford } \\
\hline & & & $\begin{array}{c}\text { All } \\
\text { Patients }\end{array}$ & $\begin{array}{c}\text { All } \\
\text { Opera- } \\
\text { tions }\end{array}$ & & $\begin{array}{c}\text { All } \\
\text { Patients }\end{array}$ & $\begin{array}{c}\text { All } \\
\text { Opera- } \\
\text { tions }\end{array}$ \\
\hline $\begin{array}{l}\text { Age } \\
\text { (yrs) }\end{array}$ & $\begin{array}{l}20-44 \\
45-64 \\
65+\end{array}$ & $\begin{array}{c}0 \cdot 8^{*} \\
5 \cdot 9 \\
27 \cdot 3\end{array}$ & $\begin{array}{c}0.35 \\
3 \cdot 2 \\
19 \cdot 7\end{array}$ & $\begin{array}{c}0 \cdot 38 \\
4 \cdot 1 \\
23 \cdot 0\end{array}$ & $\begin{array}{c}0.4^{*} \\
5.5 \\
32.1\end{array}$ & $\begin{array}{c}0.07 \\
3.8 \\
26.4\end{array}$ & $\begin{array}{c}0.11 \\
5 \cdot 1 \\
30 \cdot 1\end{array}$ \\
\hline
\end{tabular}

- Rate for age 15-44
TABLE III

OPERATION RATES IN OXFORD AND ISRAEL (Halevi and Landau, 1962); SENILE CATARACT EXTRACTIONS, PATIENTS PER 10,000 PER YR

\begin{tabular}{|c|c|c|c|c|c|c|c|}
\hline \multicolumn{2}{|c|}{ Sex $\quad}$. & \multicolumn{3}{|c|}{ Male } & \multicolumn{3}{|c|}{ Female } \\
\hline \multirow{2}{*}{ Area } & & \multicolumn{2}{|c|}{ Israeli } & \multirow{2}{*}{$\begin{array}{l}\text { Ox- } \\
\text { ford }\end{array}$} & \multicolumn{2}{|c|}{ Israeli } & \multirow{2}{*}{$\begin{array}{l}\text { Ox- } \\
\text { ford }\end{array}$} \\
\hline & & $\begin{array}{c}\text { Euro- } \\
\text { pean }\end{array}$ & Oriental & & $\begin{array}{c}\text { Euro- } \\
\text { pean }\end{array}$ & Oriental & \\
\hline $\begin{array}{l}\text { Age } \\
\text { (yrs) }\end{array}$ & $\begin{array}{l}40-49 \\
50-59 \\
60-69 \\
70+\end{array}$ & $\begin{array}{r}1 \cdot 42 \\
4 \cdot 50 \\
16 \cdot 68 \\
40 \cdot 36\end{array}$ & $\begin{array}{r}3 \cdot 76 \\
15 \cdot 75 \\
32 \cdot 73 \\
63 \cdot 30\end{array}$ & $\begin{array}{r}0 \cdot 28 \\
2 \cdot 29 \\
7.07 \\
19 \cdot 70\end{array}$ & $\begin{array}{r}1 \cdot 30 \\
5.49 \\
21.93 \\
38 \cdot 33\end{array}$ & $\begin{array}{r}4 \cdot 54 \\
15.09 \\
29.57 \\
50 \cdot 31\end{array}$ & $\begin{array}{r}0.09 \\
2.49 \\
8.80 \\
24.70\end{array}$ \\
\hline
\end{tabular}

\section{Discussion}

It is highly likely that virtually all the cataract extractions carried out in the population defined for this study are in fact included. There is no evidence that more than a small number of private patients go elsewhere for their operations, and even if the number doing so were as large as the number of private patients operated upon in Oxford, the maximum error would be no more than 10 per cent.

The relationship between the prevalence of cataract in a population and the cataract extraction rate is certainly complex, but the main factors likely to influence the relationship can at least be identifiedo and described, if not measured. These factors may be called the maturation rate, the indications for opera tion, the "operation ratio", and the "backlog" effect".

By the maturation rate is meant the rate at which clinically identifiable cataract reaches a degree necessitating operation. This is to define maturation in a sense implying need for operation, rather than in a descriptive clinical or pathological sense. A maturation rate so defined could be calculated for a population surveyed for cataract, and such a rate might well be a useful index of factors affecting cataract formation, and thus a clue to aetiology. However, the population surveyed would have to be very large or the duration of the follow-up considerable, for the operation rates found in this study ( $<6$ per 10,000 per year) to provide significant numbers.

The indications for operation are probably best defined by the distributions of visual acuities in both eyes at the time of operation. Valid comparisons between different series clearly necessitate the statement of distributions of this kind. In the present study, Fig. 3 (opposite) shows that the visual indications even for the first operation for senile cataract vary with age and sex in a complex manner. In both sexes the pre-operative visual acuity in the operated eye tends to be higher the older the patient. For the other eye, the reverse is true for men, since 

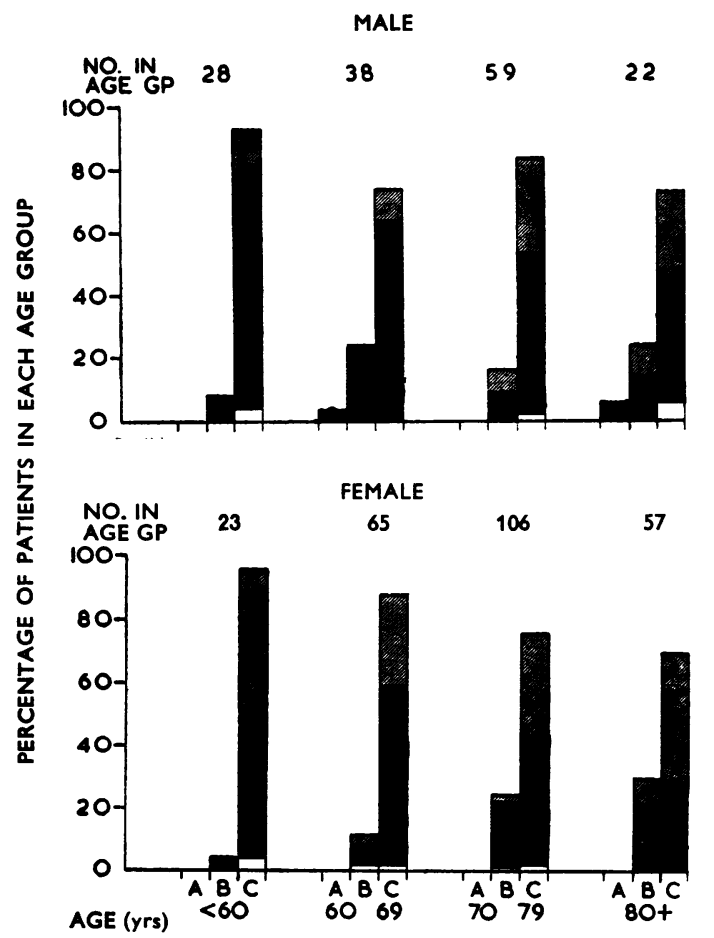

PRE-OP. VISUAL ACUITY

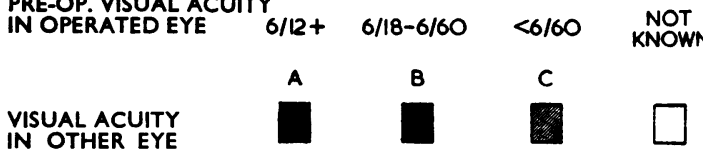

FIG. 3.-Relation between age, sex, pre-operative visual acuity in the operated eye, and visual acuity in the other eye, at the time of first operation for senile cataract.

The height of the main column indicates the percentage of patients in each age group with pre-operative visual acuity in the operated eye of $6 / 12$ or better, $6 / 18$ to $6 / 60$, or less than $6 / 60$; the cross hatchings within the columns show the distribution of visual acuities in the other eye at the time of operation.

the proportion of eyes with an acuity of $6 / 12$ or better falls, and that with less than $6 / 60$ rises with increasing age. Among the women under 70, the proportion with an acuity in the other eye of $6 / 12$ or better is one-third and with less than $6 / 60$ three times that among men under 70 . Over the age of 70 there is little difference between the sexes. This implies that a man of working age will tend to be operated upon for senile cataract when he has very poor vision in one eye and good vision in the other, while a woman of any age or an older man will not tend to be operated upon until vision is poor in both eyes.

This means that the operation rates at different ages and in the two sexes are not strictly comparable, though it is difficult to see how they can be corrected and remain meaningful. It is probably more satisfactory simply to state the rates and the visual indications for operation at different ages.

The operation ratio is defined as the proportion of patients fulfilling the indications for operation who are in fact operated upon. This is very hard to estimate. Very few patients were admitted to the Oxford Eye Hospital in the period surveyed for operation for cataract and discharged without operation, but some were doubtless seen but never admitted because they were considered unfit or refused operation. The presence of other ocular disease, such as senile macular degeneration, diabetic retinopathy, or myopic choroido-retinal degeneration, may also decide against operation. According to Sorsby (1962), one-third of those certified as blind in England and Wales because of cataract are considered unfit for operation. But a study of the hospital records of a small number of patients registered in Oxford as blind on account of cataract shows that many have in fact other serious ocular disease, only a very few being considered unfit for operation on general grounds. In some parts of the country patients are registered as blind because of cataract in order to obtain the benefits of registration while awaiting operation. Arguments from figures for blindness certified as due to cataract are thus extremely doubtful. Nevertheless, a change in the operation ratio as defined may well be, in part, responsible for the fact that the operation rates found in this study for patients aged over 80 are not as great as would be obtained by projection from the rates for younger patients.

Finally, Sorsby (personal communication, 1964) points out the existence of what may be called "the backlog effect". When ophthalmic services are being developed and for some time afterwards, there will be a backlog of patients needing operation but not yet operated upon. While this backlog is being worked off, the operation rates will be artificially high. Sorsby suggests that this may explain the differences between the rates for Oxford and for England and Wales as a whole shown in Table II. The ophthalmic services have been well developed in Oxford for many years, and the backlog may well be small compared with that for the country as a whole. He further suggests that this effect may account, at least in part, for the higher rates in Israel, and perhaps for the higher rates in Israelis of Oriental origin (Table III). The differences are, however, substantial, and other factors are by no means excluded. Repetition of the investigations at a later date would help to clarify the problem.

When all these factors are taken into account as far as may be, it seems likely that the operation rates 
for cataract, and particularly perhaps the rates for first operation for senile cataract, may prove to be an index of the prevalence of cataract in a population. The present study shows that between the ages of 60 and 90 years, senile cataract extraction increases nine-fold, and is commoner in women than in men. Outside this age range, the numbers of patients operated upon are very small, and the possibility of error consequently very large. It is not known whether these findings indicate an increase in prevalence of cataract with age or an increase in maturation rate, or, as is perhaps most likely, in both. Only large-scale field studies can provide the necessary information.

\section{SUMMARY}

A review has been made of 690 cataract extractions carried out in the Oxford Eye Hospital in 1957-62 on patients living in a defined area around Oxford.

Diabetic and secondary cataract together account for 25 per cent. of extractions.

The rate of first extraction of a senile cataract in the population increases nine-fold between the ages of 60 and 90 years.
The distribution of visual acuities in the operated eye and in the other eye at the time of first operation are discussed, and the factors relating extraction rates for senile cataract to the prevalence of senile cataract are outlined.

It is a pleasure to thank Mr J. P. F. Lloyd, Mr A. C. L. Houlton, and Mr V. B. Purvis for permission to study their patients' records. Thanks are due to them and to Mr M. H. Luntz, Dr T. B. Stephens, Dr D. Sevel, Mr J. M. D. Burns, Dr E. D. Acheson, Dr J. G. Evans, Mr P. A. Graham, and Mr F. C. Hollows for assistance, advice, and criticism.

\section{REFERENCES}

Acheson, E. D. (1964). Brit. J. prev. soc. Med., 18, 8.

Caird, F. I., Hutchinson, M., and Pirie, A. (1964). Brit. med. J., 2, 665.

Fuchs, A. (1960). Amer. J. Ophthal., 49, 1039.

General Register Office (1964). "Census 1961, England and Wales, County Reports, Oxfordshire and Berkshire". HMSO, London.

Halevi, H. S., and Landau, J. (1962). Brit. J. Ophthal., 46, 285.

Sorsby, A. (1962). Exp. Eye Res., 1, 296. (1964). Personal communication.

Working Party (1962). Brit. med. J., 1, 1497. 